總

括

著者等の考案せる電氯分銅法に於ける陽極粗銅中の夾雜物の行第を攻究する目的にて此電解浴中に於ける銅 の電位を測定せり大蹬 $E_{h}=0.09-0.12 V\left(25^{\circ}\right) 0.07-0.10 \mathrm{~V}\left(45-50^{\circ} \mathrm{C}\right)$ にして現行法に於ける銅の電位より 著しく早なり份此測定に於ける二三の觀察を記せり

（東京帝國大學工學部應用電埭化學及光化學研究室）（炤和四年六月--..七日受理）

\title{
鹽化第一銅を用ふる電氣分銅法(第四報) 電流密度と電極電位との關係
}

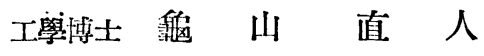 \\ 工學士 野 田稻 吉
}

絠言

此分跲法に於いて粗銅中つ夾雜物の行雼を檢討する前提として第三報に於て此電浴中の銅の本衡電位に就て

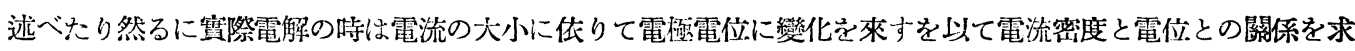
め電解中の狀態を知らんとせり之を今報告せんとす

\section{测 定 方 法}

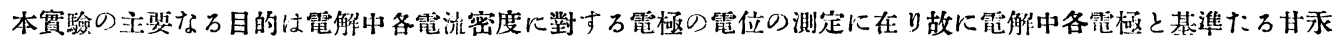
電㥛とひ間の起電力即 $+\mathrm{Hg} / \mathrm{HgCl} .0 .990 N \mathrm{HCl} / 1 .(N . \mathrm{kCl} /$ 電解液 $/ \mathrm{Cu}$ (電極)一右湘定せり低し測定の結果は 此起電力より甘我電極の電位 $\left(25^{\circ} E_{h /}=0.2753 \mathrm{~V}, 50^{\circ} E_{h}=0.2708 \mathrm{~V}\right)$ な引き $E_{h}$ として表はせり

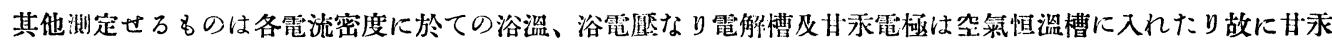
電極は恒溫慒の摆度か得たれども電解慒の電浴の溫度は電流にて熱せられ又窒素にて冷され多少異なれり（第三 郝參照)

電解槽、窒素導入管、起電力測定裝置、恒淄槽等悉く第三報と同一なれば再び此處に記せず

測定の稍詳細长述ぶれば次の如し

各實驗に於て先づ本衡電位方讀みて後極少き電流な通じ電極需位略一定すれば更に電流か增し逐次斯くして各 電流密度に對すち電㥛電位危冰め多くは $5.0 \mathrm{amp} / \mathrm{dm}^{2}$ に至り(或ものは $12.5 \mathrm{amp} / \mathrm{dm}^{2}$ 过又或ものは $3.0 \mathrm{amp} / \mathrm{dm}^{2}$

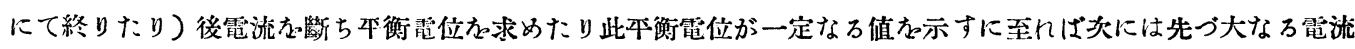

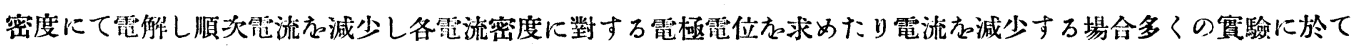

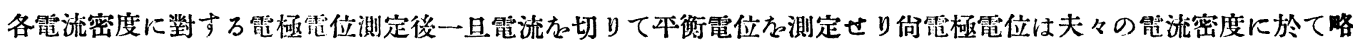

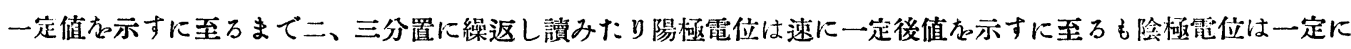
達する時間比較的長く殊に小電流密度の場合は容易に一定せざりき然れどもぜラヂンか合まざる液にて大電流密 度にて電解する時に陰極面は次籍に粗となり有效賽面積塯加するれ以て除極電位測定は成万可く速に行へりがラ

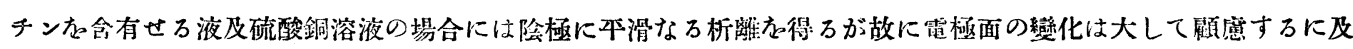

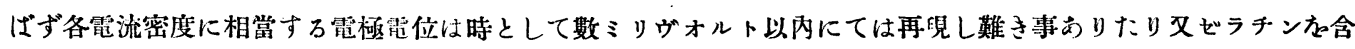
まざろ液にての㓌極電位は電流上昇の時と下降の時と去此較するに下降の時の值は上昇の時り值に比して若干ミ リヴオルト贵なりきその主原因は結晶粗となり麗極有效面積增加し從つて實際の電流密度の減少する篇なり本報

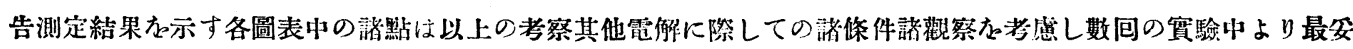
當なりと信ぜらるる值なとりたるものなり 
使用せる液及び電解條件

使用せる液の組成次の如し（第三報より再出）

$\begin{array}{ccllcc}\text { 液名 } & \mathrm{KCl} \text { 或は } \mathrm{NaCl} & \mathrm{HCl} & \mathrm{CuCl} & \mathrm{Cu} \text { (液に對し) } & \text { だラチン } \\ \mathrm{A} & 2.84 M \mathrm{KCl} & 0.74 M & 0.78 M & 3.75 \% & \text { なし } \\ \mathrm{B} & 2.84 & 0.72 & 0.65 & 3.23 & 1 \mathrm{~g} / l \\ \mathrm{C} & 4.03 & 0.96 & 1.023 & 4.74 & \text { なし } \\ \mathrm{D} & 4.09 & 0.91 & 1.008 & 4.66 & 1 \mathrm{~g} / l\end{array}$

$\mathrm{A}$ と $\mathrm{B}, \mathrm{C}$ と $\mathrm{D}$ との主なる差はゼラチンの有然に在り又 $\mathrm{A}, \mathrm{B}$ と $\mathrm{C}, \mathrm{D}$ との主なる差は全監素量が $\mathrm{C}, \mathrm{D}$ に於て大にして含銅率も亦大なる點にあり

ゼラチンは一旦水に溶解し其溶液を監液に調合して電解液を調製す一旦水に溶解せるゼラチンは監液に入り て㠜固し液は薄く白濁す此濁りは數日寸るとも消えず D 液は此期間中に使用せり然るに B液は調製後使用ま で 70 日を經渦せるものにして全く透明なり㠜固せる部分は電解液貯器の底に沈澱し居たり

佾現行法と比較の䉆に上上と全く同一裝置を用るて次の組成の硫酸銅溶液の電流密度電極電位:曲線を求めた り

$$
\begin{array}{llll}
\mathrm{CuSO}_{4} & 0.63 M / l & \text { 郎 } 5 ~ & \mathrm{Cu}=40 \mathrm{~g} / l \\
\mathrm{H}_{2} \mathrm{SO}_{4} & 2.05 M / l & \text { 郎 } 5 & \mathrm{H}_{2} \mathrm{SO}_{4} 200 \mathrm{~g} / l
\end{array}
$$

此組成は近時米國に於ける分銅作業に用るらるるものに準じたるものなり(S. Skowronski：Trans. Amer. Electroch. S $, c ., 1927,51)$ 此液にても測定中空素を通じて攪挥せり

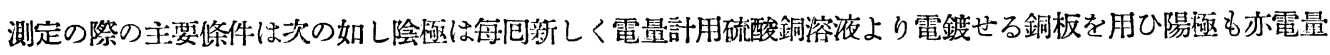

\begin{tabular}{|c|c|c|c|c|c|}
\hline 實羷番號 & 曲線番號 & 使用液 & $\begin{array}{l}\text { 恒 溫槽溫度 } \\
\text { (或は麗極㳢度) }\end{array}$ & $\begin{array}{c}\text { 雪流密度範圍 } \\
\mathrm{amp} / \mathrm{dm}^{2}\end{array}$ & 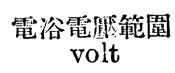 \\
\hline 1 & 1 & $\mathbf{A}$ & $25^{\circ}$ & $0.005-5.0$ & $0.005-0.47$ \\
\hline 2 & 2 & A & $50^{\circ}$ & $0.05-12.5$ & $0.02-0.70$ \\
\hline 3 & 3 & B & $2 j^{\circ}$ & $0.05-5.0$ & $0.04-0.48$ \\
\hline 4 & 4 & $\mathrm{~B}$ & $50^{\circ}$ & $0.05-5.0$ & $0.02-0.39$ \\
\hline 5 & 5 & $\mathrm{C}$ & 常溫 & 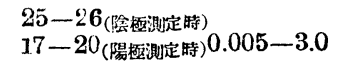 & $0.005-0.37$ \\
\hline 6 & 6 & $\mathrm{C}$ & " & $0.01-6.0$ & $0.01-0.42$ \\
\hline 7 & 7 & $\mathrm{D}$ & " & $0.005-4.0$ & $0.01-0.125$ \\
\hline 8 & 8 & $\mathrm{D}$ & " & $0.005-6.0$ & $0.005-0.48$ \\
\hline 9 & 9 & $\begin{array}{l}\mathrm{CuSO}_{4} \\
\mathrm{H}_{2} \mathrm{SO}_{4}\end{array}$ & $50^{\circ}$ & $0.10-5.0$ & $0.02-0.35$ \\
\hline
\end{tabular}
計用硫酸銅溶液より厚約 $1 \mathrm{~mm}$ 電着せるものなり

實驗 5 万至 8 にては甘承電極は常溫に保ちその溫度は器中に挿入せる寒喛計にて測りたり

\section{絬果及び觀察}

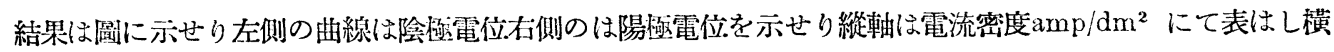
軸は電位を $E_{h}$ ににて表はせり平衡電位は垂直の直線にて示せり

陰整電位. 此曲線は大體三つの部分に分れたり

1. 電流密渡小なる處の直線部分

2. 稍電硫密度大なる處にて曲線の倾斜の急變する部分

3. 電流密度大なる處の曲線は垂直に近く急昇する部分 

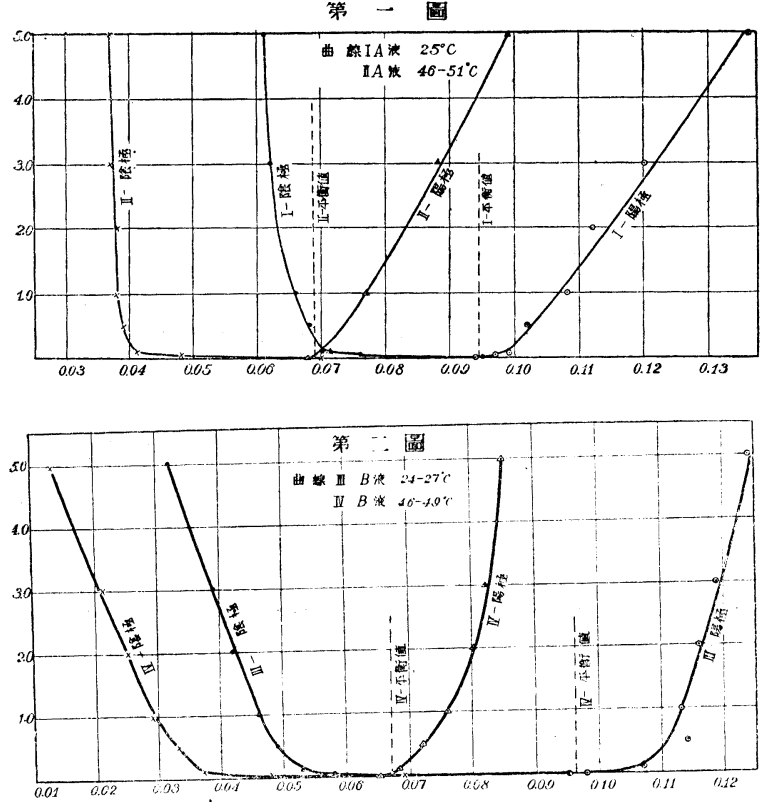

(1) $0.01 \mathrm{amp} / \mathrm{dm}^{2}$ にては陰淒電位は平衡 電位と大差なし $0.05 \sim 0.10 \mathrm{amp} / \mathrm{dm}^{2}$ の間 にては著しく變り此聞は電流電位曲線は㱠 んど水平に走る從つて電流の僅の變化も電 位に著しく影響を及ぼし此處にては陰頇面 に未だ銅の析出せるを認められず

(2) 0.05 乃至 $0.10 \mathrm{amp} / \mathrm{dm}^{2}$ の電流密度 にては電極電位は數十分に百つて一定せず 初め徐々に早となり或ものは後再び徐々贵 となれり此電位の變動は相當大にルて時と して數ミリヴゥルト或は夫以上にも達せる 事ありたり且此電流密度の附近に於て陰阻 面に新に銅の析出し初むるを認めたり併し て此電流密度に相當する電梌電位測定の時 聞の長短或は電位變動の終未琴の取方等に
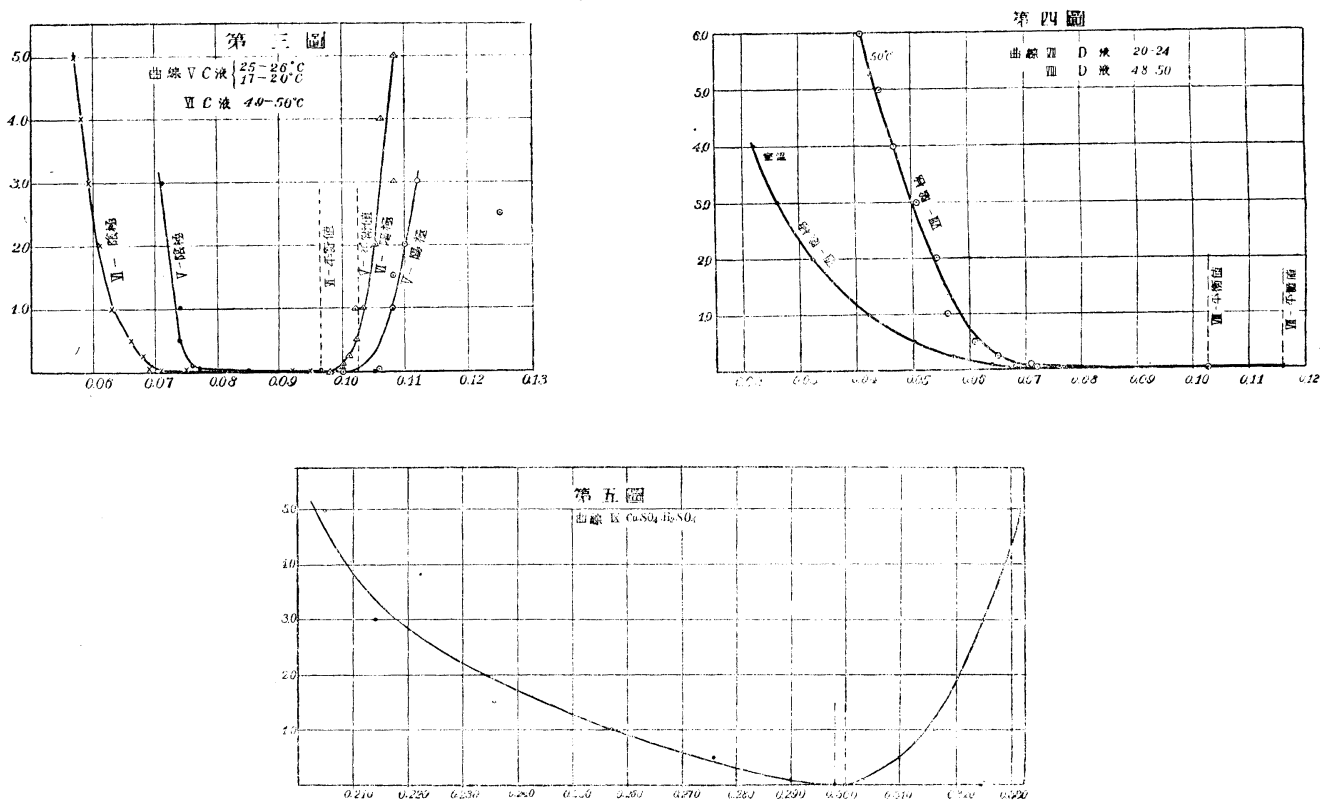

依りて曲線の曲析點に 2〜3 ミリヴォルト或は夫以上の差を生じたり時としては更に大なる電流密度に相當せ る電桖電位の方が却つて贵なる事もありたり

(3) $0.5 \mathrm{amp} / \mathrm{dm}^{2}$ 以上の電流密度にては電流の變化に依る電隼電位の變化は僅少にして曲線は垂南に近く 上昇すゼラチンを含める液を用るたる場合は電流密度の大なる場合の倾斜は稍緩なり此範圍にては一旦電流を 增したる直後は電亚電位著しく早なる値を示せども急速に貴となりて略一定值を示すゼラチンを含まざる液に 
は（之を含む液に比較し）徐々に更に贵となる電流密度の大なる程此の現象は著し此現象の成因は次の如しと 思はる郎ち初め其の電流に相當する丈銅イオンが放電するや電程附近のイオン濃度は激減し鯊に著しく草な る值を示す電㥛附近のイオン濃度激減すれば漺散は急速となり逐にイオンの供給と放電とが相殺するに至つて 定常狀態となり電位は一定するものならん $(\mathrm{A})$ 及 $(\mathrm{C})$ 液にて更に徐々に貴となるは後說する如く電極面積の變 化に歸因寸るものなり(B)及(D)液にては全く一定なる值を示せり

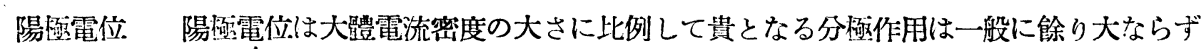
$25^{\circ} \mathrm{C}$ 於ける現象 $0.5 \mathrm{amp} / \mathrm{dm}^{2}$ 位の電流密度より陽㢦面に暗赤色となれる部分認められ陽保電位は少しく 不定の值を示し數ミリヴォルト上下゙する事ありたり斯る現象の起る時は電流も僅變動せり陽極に變色せる部分 の認めらるる頃より電解容器の底に黑赤色乃至赤銅色の徽紛末(以下假に銅粉と稱す)を生ず電極面の變色せる 部分法銅化合物(酸化銅？)の膜愿にして液中に吹出さるる窒素によりて吹落され容器底に預るものならん銅濃 度比較的少なき液 $(\mathrm{A})$ 及 $(\mathrm{B})$ にては $5.0 \mathrm{amp} / \mathrm{dm}^{2}$ 前後の電流密度となれば陽極の㬐赤色部は黑夕を增し電位は 屡々 10 ミリヴォルト以上も變動することありたり電流を更に增加すれば陽極全面は黑赤色となり $10.0 \mathrm{amp} /$ $\mathrm{dm}^{2}$ 以上の電流を通ずれば陽極的酸化起り液は逐に褐變せり銅濃度比較的大き液 $(\mathrm{C})$ 及 $(\mathrm{D})$ に於ても同樣の現 㕰を見らる之の場合は攪拌の多少により少しは異れども $2 \sim 3 \mathrm{amp} / \mathrm{dm}^{2}$ 或は $5.0 \mathrm{amp} / \mathrm{dm}^{2}$ 頃の電流密度に於 て陽極的酸化起り攪拌の不充分なる所より焚火の煙の如く液中の黑褐色液の撗り行くを見たり陽極的酸化の起 る時は電極電位は著しく貴となる

$50^{\circ} \mathrm{C}$ に於ける現像＼cjkstart陽整電位は割合に一定せる值を示す $2.0 \mathrm{amp} / \mathrm{dm}^{2}$ に於て赤銅色銅粉現はれ鄮汼不充分 なる時は陽極面に變色せる部分を認めたり 7.0 amp $/ \mathrm{dm}^{2}$ の電流密度に於ても極面の大部分に變化なく $12.5 \mathrm{amp} /$ $\mathrm{dm}^{2}$ の電流る通ずるも夜は變化せず但し銅濃度比較的大なる液(C)及(D)にては $5.0 〜 6.0 \mathrm{amp} / \mathrm{dm}^{2}$ の電流密 度の時に電樰電位は寔々著しき變化を爲せる事山りたり $50^{\circ} \mathrm{C}$ の電解にて生ずる銅粉は時として黑褐色を帶ぶ る事もありたれど多くは赤給色を有しその外觀金屬銅の如し

以上はゼラチンを含む液にも含まざるものにも共に觀察し得られたる現象なり (D)液にて $25^{\circ} \mathrm{C}$ 場合はゼ ラチンは終始凝固し液は僅に白濁し居たり $50^{\circ} \mathrm{C}$ の場合は電解開始後漸次にして次第に唀明なる液となれりゼ

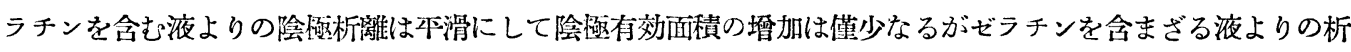
離は 2〜3amp/ $/ \mathrm{dm}^{2}$ 頃より次第に粗面となり 4 5 $\mathrm{amp} / \mathrm{dm}^{2}$ 頃には陰極周邊に針狀突起を認められたり從つて

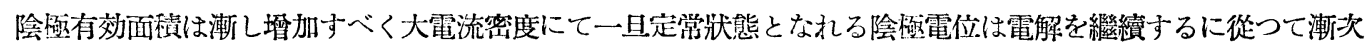

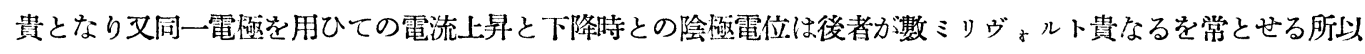
なりゼラチンを含める液にては電流上昇時と下降時との電極電位は 1 2 ミリヴォルトの範園にて一致せり

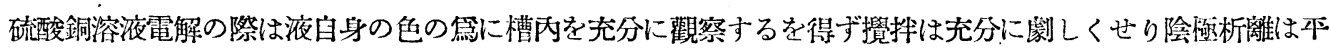
滑なり容器底に銅粉を認めたり

\section{結果の考祭}

1. 大體の電位。此電浴中の銅の平衡電位は第三報及本報の測定に依り現行法の銅の電位に比し $0.2 ら ゙$ ォルト程も早なり而して本報に於ける分植の程度を見るに左程大ならざる故上記の關係を覆すことなし 今比較に便する䉆に實際的と思はるる電流密度にての $50^{\circ} \mathrm{C}$ 附近に於ける電位を示さむ 


\begin{tabular}{ccccc} 
& \multicolumn{2}{c}{ 除極電位 $\left(E_{h}\right)$} & \multicolumn{2}{c}{ 陽極電位 $\left(E_{i}\right)$} \\
雷流密度 $\mathrm{amp} / \mathrm{dm}^{2}$ & 1 & 3 & 1 & 3 \\
液 $\mathrm{A}$ & $+0.038 \mathrm{~V}$ & $+0.037 \mathrm{~V}$ & $+0.077 \mathrm{~V}$ & $+0.088 \mathrm{~V}$ \\
$\mathrm{~B}$ & 0.029 & 0.021 & 0.076 & 0.082 \\
$\mathrm{C}$ & 0.063 & 0.059 & 0.103 & 0.108 \\
$\mathrm{D}$ & 0.056 & 0.051 & - & - \\
$\mathrm{CuSO}_{4} \cdot \mathrm{H}_{2} \mathrm{SO}_{4}$ & +0.259 & +0.216 & +0.318 & +0.327
\end{tabular}

2. 夾雜物の行雹に就ての考察 先つ陽植に就て考へむに陽㥛の銅の電位を $E_{h}=0.10 n$ と假定せむ今 粗銅中に $M$ なる金屬が夾雜し此金屬が溶解して $\mathrm{n}$ 價の $M^{+n}$ なるイオンを作り其活量 $a \mathrm{x} に$ 至りたるとき $0.10 \mathrm{~V}$ に澾するものとせむ然らば粗銅の電位.が電解中 $0.100 \mathrm{~V}$ に保たるる故 $M$ なる夾雜物は $a \mathrm{M}$ に相當する濃度ま

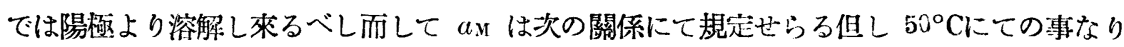

$$
\frac{0.064}{n} \log a_{\mathrm{M}}=0.100-E_{\mathrm{Y}}^{\circ}
$$

$E^{\circ} \mathrm{M} \quad$ は $50^{\circ} \mathrm{C}$ に於ける標準起電力なりイオン化倾向の大なる $\left(E^{\circ} \mathrm{M}\right.$ ガ早なる $)$ 金屬例へば $\mathrm{Zn}\left(E^{\circ}{ }_{25}^{\circ}=-0.75 \mathrm{SV}\right.$ 以下類項の此括孤內の數字は $E_{25}^{c}$ なり $) \mathrm{Fe}\left(\mathrm{Fe}^{++}-0.441\right), \mathrm{Cd}(-0.3976), \mathrm{Ni}(-0.218), \mathrm{Sn}(-0.136), \mathrm{Pb}(-0.1$ 22)に於て上式を滿足せしむ可き $a \mathrm{M}$ は甚だ大にして勿論陽極にて溶解すべし

イオン化傾向の小なる銀 $(+0.7995)$ に於ては $50^{\circ} \mathrm{C}$ に於ける $E^{\circ}$ が $25^{\circ} \mathrm{C}$ と大差なしと見るときは $a_{A \mathrm{~g}}$ が

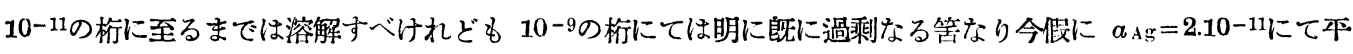
衡になるものと寸れば $\mathrm{AgCl}$ の溶解度積 $\left.\left(L_{\mathrm{Ag}}=a_{\mathrm{Ag}} \times a_{\mathrm{Cl}}\right)^{-}\right)$が $50^{\circ} \mathrm{C} に て 10-10 の$ 析なるが故に $a_{\mathrm{Cl}}$ が餘程大 ならずむば AgCl ば沈澱せざる可し之を要するに $\mathrm{Ag}^{+}$に就ては $\mathrm{AgCl}$ の沈澱を生ずる程の濃度に至らざる 內に銀は溶解せざるに至る筈なり然れども $\mathrm{Ag}^{+}$はCl-と錯監（例 $\mathrm{AgCl}_{2}$-)を作り互に平衡を成立するが故に 溶液中の銀の全量は餘程大なり得可し

金に就ては未だ $E^{\circ}$ が測定せられざれども餘程貴なるが故に液中に存在し得べき金イオンは著しく小なるべ ᄂ

陰極に就て考ふるに銅の電位を $E_{h}=0.05$ と探るときは前記同樣の考察にて $\mathrm{Zn}, \mathrm{Fe}, \mathrm{Cd}, \mathrm{Ni}, \mathrm{Sn}, \mathrm{Pb}$ 等は 陰極に析出せず $\mathrm{Ag}$ に就ては $\mathrm{AgCl}$ にて飽和せるほど（但し $a_{\mathrm{Cl}}$ ーが $1.0 M$ 以上は此電浴中に無きものとす） の $a_{\mathrm{Ag}+}+$ ならば陰極に析出すべし

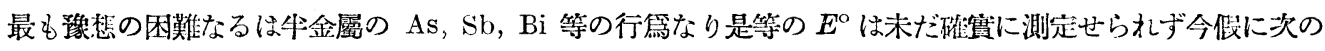
第二行目の數を假定するならば電解液中に液に對して各 $0.1 \%$ 宛存在し其活量係數が 0.1 なりとせば次の結果 となるべし

$\begin{array}{cccccc} & E^{\mathrm{o}} & F_{\mathrm{M}} & & E^{\mathrm{O}} & E^{\mathrm{M}} \\ \mathrm{As} / \mathrm{As}^{+++} & +0.28 \mathrm{~V} & 0.22 v & \mathrm{Bi} / \mathrm{Bi}^{+++} & +0.04 & 0.02 \\ \mathrm{Sb} / \mathrm{Sb}^{+++} & +0.10 & 0.06 & & & \end{array}$

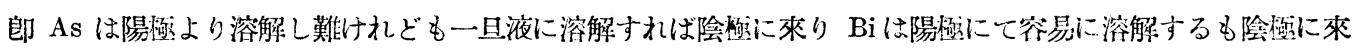
らず $\mathrm{Sb}$ は最も銅の行瓷に近くして銅に伴ひ易し然礼ども是等牛金屬行䉆の推諭には多分の假定が含まるる故 に頁の行䉆は䔬驗に依るの外明かにし難し 
3. 分極の大さ次に分極の大さ自身を詳細に見むとす

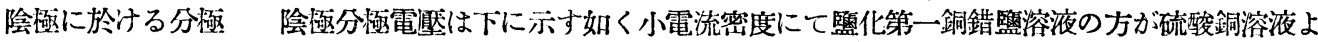
り大なるも普通に電解精斜に用ひらるる程度の電流密度 (1.0 1.5 amp $\left./ \mathrm{dm}^{2}\right)$ にては殆んど大差なく其より大

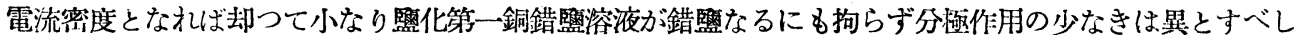

浴溫 $50^{\circ} \mathrm{C}$ に於ける陰極分渻電壓

$\begin{array}{lccc}\text { 䨤泷密度 } & 0.1 \mathrm{amp} / \mathrm{dm}^{2} & 1.0 \mathrm{amp} / \mathrm{dm}^{2} & 5.0 \mathrm{amp} / \mathrm{dm}^{2} \\ \mathrm{~A} & 26 \mathrm{mV} & 32 \mathrm{mV} & 33 \mathrm{mV} \\ \mathrm{B} & 32 & 4.0 & 56 \\ \mathrm{C} & 27 & 32 & 36 \\ \mathrm{D} & 32 & 42 & 59 \\ \mathrm{CuSO}_{4} \cdot \mathrm{H}_{2} \mathrm{SO}_{4} & 3 & 41 & 93\end{array}$

前表に見るが如く電解液がゼラチンを含む時は然らざる時に比して分極大なり

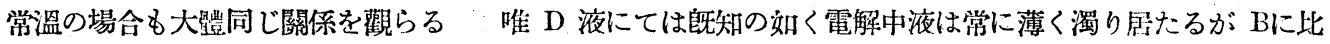
して分極大なるは當然なるべし其他の場合は電解中液は孰れも透明なりき

$\mathrm{D} の 50^{\circ} \mathrm{C}$ の時は最初液は薄く濁り居なるも電解中漸次透明となれり而して分極は $\mathrm{B}$ と等しくなれり即ち調製 後數十日を經ゼラチンの透明に溶解せるもの（郎ちB）も調製後數日電解時に初めて透明に溶解せるもの（郎 ちD）も㓌極分淡は同樣なり實際工場等にて取扱はるる場合のゼラチンの狀態も之に近きものなるべし

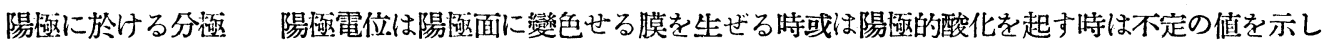
其の他の實驗上の諸條件 (溫度、濃度、攪䢁等) の差異より受る變化の範圍に於てゼラチンの有無が陽極分極

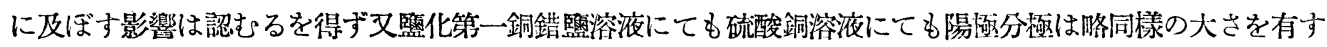

$$
\text { 總括 }
$$

1. 此の電氣分鋼法の電浴中の銅除樵及び銅陽㧹の電位.を測れり

2. 其電位より粗銅中の夾雜物の行罵を考察せり

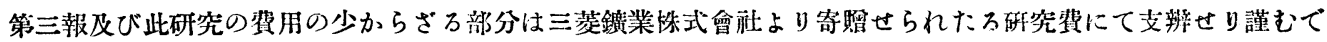
同新に謝意古表す 